\title{
The Construction and Practice of "1+5+1" Innovation and Entrepreneurship Practice Education System in Applied Universities
}

\author{
Han Jiao \\ Innovation and Entrepreneurship College \\ Liaoning Institute of Science and Technology \\ Benxi, China
}

\begin{abstract}
Under the background of "general entrepreneurship" and "public innovation", the paper is based on national development strategy driven by innovation and deep understanding of applied innovative entrepreneurial talents. The main emphasis of the paper is placed on the school-running orientation of application and the target of talent-cultivating. The paper analyzes series of theoretical and practical problems of the top-level design for personnel training, the teacher troop, integration with production services, and so on. It takes practice system construction as the core and incubation system construction as the foothold. The paper is to construct practical $" 1+5+1 "$ cultivation system of innovation and entrepreneurship supported by construction of security system. It is of significance to provide the replicable and scalable educational model of creative reform of education and teaching and mechanism of innovation entrepreneurship for application colleges and universities. It demonstrates the effective transitional breakthrough and development in application colleges and universities.
\end{abstract}

Keywords-application colleges and universities, innovation and entrepreneurship, innovation and entrepreneurship education, practical education, system

\section{INTRODUCTION}

Under the wave of "general entrepreneurship" and "public innovation", in "Work Opinion as to Vigorously Promote the Innovation and Entrepreneurship Education and College Students' Self-employment in Higher Learning Institutions”, "Basic Requirements on the Entrepreneurship Education and Teaching of Common Colleges and Universities", "Opinions on Deepening Reform of Innovation and Entrepreneurship Education in Institutions of Higher Learning." and "On the Guiding Opinions of Leading Parts of Ordinary Undergraduate Course Colleges and Universities to Application Institutions of Higher Learning." "The Outline of National Development Strategy Driven by Innovation” and the reports of the Party's 18th and 19th there is an important deployment about cultivation of creative talents , specifically about to implement the development strategy driven by innovation, to deepen the reform of the institutions of higher learning innovation entrepreneurship education, to take the innovation entrepreneurship education as a breakthrough for the development of higher education reform , to continuously strengthen the consciousness of students' spirit of innovation, entrepreneurship and innovation entrepreneurship ability ${ }^{[1]}$.

Transformation and development of application universities is compatible, cross with education reform of innovation entrepreneurship. How to build practical cultivating system of innovation and entrepreneurship based on the transformation , the fusion of production and education and multidimensional collaborative ,how to cultivate applied talent with innovative entrepreneurial, how to continuously improve the quality of personnel training are the urgent concerns of the time. But because of the problems on the design at the top level, talent training, team construction of teachers, integration of production and education, service for local places and mechanism system, innovation entrepreneurship education reform faces huge adjustment and receives wide attention from all walks of life.

\section{PROBLEMS IN THE CONSTRUCTION OF EDUCATION SYSTEM OF INNOVATION AND ENTREPRENEURSHIP IN APPLICATION UNIVERSITIES}

\section{A. Problems in top-level design}

We should explore how to integrate innovation and entrepreneurship education into the top-level design and scientific planning of the university; how to combine innovation and entrepreneurship education with school transformation and development; how to deepen institutional reform; how to effectively promote the education reform of deepening university innovation and entrepreneurship; how to set up the education concept of innovation and entrepreneurship; how to build the education system of innovation and entrepreneurship in line with the school's educational goals and management concepts; and how to construct scientific innovation and entrepreneurship education operating mechanism and implementation path.

\section{B. Problems in personnel training}

We should explore how to conduct the deep integration between education and professional education; how to effectively connect the first class with the second class to improve students' practical ability; how to build the interdisciplinary talent training mechanism; how to build a practice platform for innovation and entrepreneurship. 


\section{Problems concerning the construction of teaching staff}

We should explore how to build a team of innovative and entrepreneurial teachers; how to comprehensively improve the teaching level of all school teachers and promote the reform of teaching through the training of innovative entrepreneurship teachers; how to combine construction of innovative and entrepreneurial teaching staff with the whole school teacher training to get mutual promotion.

\section{Problems concerning the integration of industry and education and the service for local places}

We should explore how to improve the conversion rate of scientific and technological achievements through innovation and entrepreneurship education; how to integrate innovation and entrepreneurship education with industry and education; how to get school-enterprise cooperation and deep integration of collaborative education.

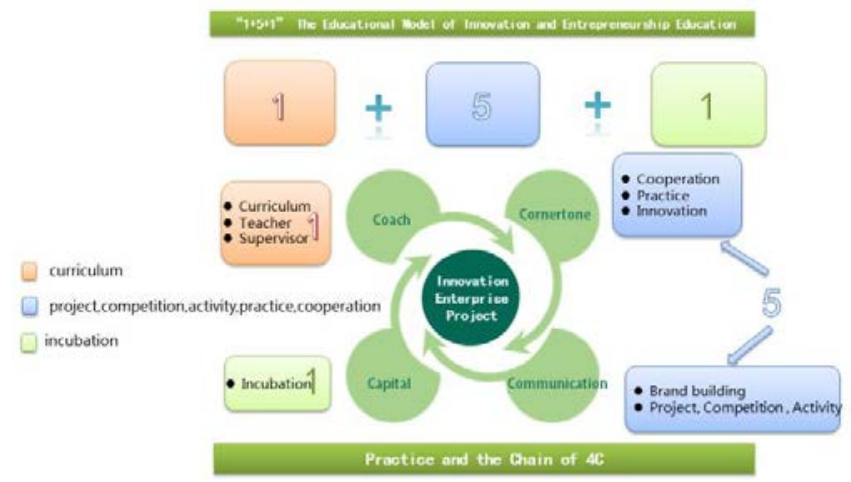

Fig. 1. Education model of practical education for innovation and entrepreneurship in applied universities

III. CONSTRUCTION AND PRACTICE OF "1+5+1"

INNOVATION AND ENTREPRENEURSHIP PRACTICE EDUCATION SYSTEM

The new path of the implementation is to explore "fusion of thought and creation", "fusion of professional education and creation", "fusion of practice education and creation", "fusion of occupation guidance and creation", "fusion of culture lead and creation", "fusion of cooperative education and creation" and "fusion of service for local places and creation". The paper is to construct the innovation and the entrepreneurial practice educational system of applied university "1 + 5 + 1" (courses + project, contests, practice and activities, cooperation + incubation)(see fig. 1).

\section{A. Take cultural construction as the lead and integrate \\ ideological and political education into the whole process of education of innovation and entrepreneurship.}

Starting from the cultural concept, we construct cultural content of innovation and entrepreneurship education. In order to establish the concept of "practical innovation", we combine it with the spirit of the university. Paying attention to the toplevel design and creating a good atmosphere of innovation and entrepreneurship, we establish the concept of "being brave in practice", carry out system innovation, and constantly improve the training quality of applied talents. Establishing the concept of "perseverance", actively choosing the model, we tell good stories about school and demonstrate the power of examples. Establishing the concept of "serving the society", we vigorously promote the integration of industry and education, and enhance our ability to serve local communities. Gradually honing the culture and spirit of education, we will be "pioneering inno vative, being brave in practice, being brave in setbacks and making selfless contributions" and lead the school to education with socialist core values. At the same time, we establish the multi-dimensional fusion, multidisciplinary cross through the whole process of the innovation mechanism of entrepreneurship education and further complete the innovative entrepreneurial education and seven-aspect deep fusion. Establishing cross-department and cross-discipline, cross-major talent mechanism of innovation and entrepreneurial, integrating innovative entrepreneurship education into the whole process of talent training, we promote the deep integration of innovation, entrepreneurship education and professional education and improve applied the quality of talents training.

\section{B. Based on curriculum system construction, realize the deep integration of education and education of innovation and entrepreneurship.}

Based on the curriculum system construction, we establish innovative entrepreneurship practice course system which includes 'four stages"- liberal education foundation courses of innovation and entrepreneurship, professional innovative courses, open crossing courses and training courses for innovation ability. By setting up the sunny and entrepreneurial elite class and minoring in technology innovative major, we construct entrepreneurship curriculum system including common courses, specialized courses, elective courses which contain entrepreneurial class from the hardware, robot, intelligent transportation and other new engineering directions. We cooperate with enterprises to build an entrepreneurship college and open the connection between the university and enterprises. We publish the school-based teaching foundation material of college students' innovation and entrepreneurship, which is applicable to the construction of the modular curriculum system of transformation and development. We build a comprehensive innovation and entrepreneurship curriculum system featuring of industries, specialty of innovation and entrepreneurship, and carry out a comprehensive reform of the talent training mode with a bit of focus.

\section{Take the construction of the practical system as the core to realize the deep integration of education practice and education innovation and entrepreneurship}

With the construction of practice system as the core and the improvement of students' practical ability as the focal point, an innovative and entrepreneurial practice education system integrating project, competition, activity, practice and collaboration is to be constructed.

Project: Guided by the innovation and entrepreneurship training program of college students, the effective closed-loop connection of courses, projects, competitions, practices and coordination is to be realized and the integrated program of competition courses is to be created. 
Competition: Through various kinds of innovation and entrepreneurship competitions at all levels the "Challenge Cup", "Create Youth", "Internet +", "Three Creates" innovation and entrepreneurship competitions, we constantly improve students' innovation and entrepreneurship ability.

Activity: Through "Kechuang" brand activities, "Kechuang Tour", "Kechuang Star",” Kechuang Forum "," Kechuang Salon", "Kechuang Practice Week","Kechuang Roadshow" and "Kechuang Summer Camp" series of activities, the vitality of innovation and entrepreneurship is released and the atmosphere of innovation and entrepreneurship is created.

Practice: Creative teaching practice platform is established and laboratory open to innovative entrepreneurship education campus (center) ,provincial experimental teaching demonstration center, college students' innovative undertaking education practice base are built. Intensive efforts to the construction of laboratory and engineering training base is taken. We focus on building innovative entrepreneurial class society. A "one brand" a single "new" pattern of innovative entrepreneurial class society is to be formed. Effective connection with the first class of the second class is realized to improve students' innovative entrepreneurial practice ability ${ }^{[5]}$.

Synergy: On the basis of service for local places, focusing on the integration production and education, we actively set up multi-dimensional cooperation to meet the needs of local government, enterprise, industry, society and alumni. Collaborative innovation education platform of "Schoolgovernment “,” school-enterprise” and "school-school" are established. It is suggested that college of innovation and entrepreneurship should adopt the operation mode of industrial college to establish a stable off-campus innovation and entrepreneurship training base and a cooperative unit of production, study and research. Docking regional industry actively, cooperating with regional government on docking area of innovation of industry chain, we should serve economic chain for the innovation of the regional economic, provide important entrepreneurship research and consult for social development ${ }^{[2]}$.

\section{TAKE THE CONSTRUCTION OF INCUBATION SYSTEM AS}

THE STARTING POINT TO BUILD A SERVICE PLATFORM FOR

INNOVATION, ENTREPRENEURSHIP, PRACTICE AND EDUCATION

College students' innovative undertaking hatching base is built. The college students' innovative practical educational platform supporting service system with Incubation Park as the core of the progression is established step by step. "1 + N" guest room, collaborative innovation platform, the college students' innovative business incubation base and provincial double gen demonstration base and double gen big data platform are used for support. And innovative entrepreneurial practice, training, hatch, financing are provided. A seed fund pool is built. The base operating mode "entrepreneurial nursery - business incubation - startup accelerator" + "entrepreneurial training + angel investment + business alliance" is formed. We will gradually build a scientific and efficient big data analysis system for innovation and entrepreneurship practice for education. And data-oriented management of courses, projects, competitions, activities, practices and bases will be realized ${ }^{[3]}$.

\section{STRENGTHEN THE TOP-LEVEL DESIGN OF INNOVATION AND ENTREPRENEURSHIP EDUCATION WITH THE SUPPORT OF THE CONSTRUCTION OF A SECURITY SYSTEM}

From four aspects of the construction of security systeminstitutional guarantee, organization guarantee, teachers' support, capital support, we comprehensively strengthen the top design of innovative entrepreneurship education to build a more scientific innovation entrepreneurship education work running mechanism to keep innovation entrepreneurship education running efficiently ${ }^{[4]}$.

\section{A. Institutional Guarantee}

"Implementation Plan for Deepening the Reform of Innovation Entrepreneurship Education", "Guidelines of Strengthening Creative Education of the College", "Measures for the Administration Students' subject and Innovative Entrepreneurship Competition of the college", "Measures for the Administration students' innovative undertaking hatching base", 'Management Measures of the College Students' Innovative Entrepreneurial Project", "Measures for the Administration for the Innovative Undertaking Mentor", "The measures for the Implementation of Curriculum Construction Competition" and "Comprehensive Assessment Method of the Student Quality" are formulated to improve the system of creative education system. Incorporating innovative entrepreneurial performance measures into the secondary school teaching job performance evaluation is helpful to connect the teachers' work in the creative education indicators with the title appraisal system. Policies to encourage and motivate Innovation entrepreneurship education are made to encourage teachers to engage in innovative entrepreneurship education, teaching and guidance work. Combining the reality of school, policy inclination from the title, annual performance appraisal, the teaching work, teacher training, teaching reform project, and teaching awards is put forward. The incentives and rewards points for students to participate in the activities of innovative in identifying, credits, with explicit evaluation aspects are implemented.

\section{B. Organizational security}

1) Leading group for college students' innovation and entrepreneurship education work is established.

Leading group undertaking education work is set up in college. The group leader of college students' innovative is undertaken by the party Committee Secretary of the Headmaster. The deputy is undertaken by the head of the other school leadership. The leading group members are undertaken by head of the college of innovation business, office of teaching affairs and other departments. Leading group office is located in the college of innovation. Under the leadership of the school leadership team, it is responsible for innovation entrepreneurship education organization, coordination and implementation of the work. The innovation entrepreneurship education work leading group is also established in each department. The group leader is taken by the secondary unit 
administrator leader, responsible for the specific implementing creative education work the colleges.

2) The expert team for innovation and entrepreneurship education is formed

Innovation entrepreneurship education expert database is built in school. Some famous experts and outside campus entrepreneurship education experts and management personnel are invited to take innovation decision-making reference, counseling, guidance, quality evaluation, etc.

3) Set up special innovation and entrepreneurship work institutions

A department of innovation and entrepreneurship is set up in college which is responsible for education work of innovation and entrepreneurship. Functions scattered in educational administration, school youth corps committee, admissions, science and technology section are integrated into the job category of the department of innovation. It is defined as "secondary teaching unit", undertaking two functions of college teaching and management.

4) Special leading and working institutions of the base have been established

"Hatching base construction leading group for college students' innovative" is set up in school. Leading group of "Liaoning Institute of Science and Technology college students' innovative entrepreneurial base construction" is constituted by the secretary and the principal. The deputy team leader is undertaken by vice field head of related functional department. Specialized organization and management office is established which is responsible for the college students' innovative hatching base of the college students' innovative business incubators. The incubation base for college students' innovation and entrepreneurship is managed by the college of innovation and entrepreneurship, with a special person (director of the incubator base for college students' innovation and entrepreneurship) in charge.

\section{Qualified teachers Indemnification}

We will continue to strengthen the construction of teaching staff for innovation and entrepreneurship and build a teacher team of innovation and entrepreneurship combining full-time and part-time jobs. Through innovative entrepreneurial faculty training base, innovative entrepreneurship teachers' "ability" starts to be planned. We strengthen teachers' training through the internal training and external training to build a highquality faculty. The faculty is interdisciplinary and the combination staff of full-time and part-time entrepreneurial education with the practice guidance ability of innovation entrepreneurship and two 'cans' through online learning way and underline learning.

\section{CONCLUSION}

Based on the transformation of application-oriented universities, this paper aims to achieve "four improvements" by centering on "four transitions". " $1+5+1$ " innovation and entrepreneurship practice education system in applied universities has been widely used in Liaoning Institute of Science and Technology. It won the first prize for teaching achievements in Liaoning Province. And it increased "training quality of applied talents significantly, employment and entrepreneurial capacity significantly, ability serving local economic and social development significantly, development ability driven by innovation significantly".

\section{ACKNOWLEDGMENT}

"Research and practice of Innovation and Entrepreneurship Education system in Applied Universities- a case study of Liaoning University of Science and Technology.” Science Research Project of Liaoning Education Department in 2017. (W2017lkyqn-10)

"Research on curriculum construction of new engineering practice education innovation and entrepreneurship workshop", the second batch of production and education cooperative education projects launched by the Ministry of education in 2017. (201702038043)

"Research on innovative Entrepreneurship Education Model based on Entrepreneurial ecosystem Theory", The "Thirteenth Five-Year Plan Project" of Liaoning Province Educational Science in 2016.(JG16DB227)

\section{REFERENCES}

[1] Lu Gang, Chen Shengbing and Hu chunling "Exploration and practice of education system of innovation and entrepreneurship for college students in application-oriented colleges-- take hefei university as an example,” [J].Journal of education college, suzhou, 2017,20(05): 72-74

[2] Xue Fan "School-enterprise collaborative innovation training of high quality technical skills -- the construction practice and exploration of college students innovation enterprise park in huanghuai university”[J]. Henan Education (Higher Education), 2014(03):15-17

[3] Hao Jie, Wu Aihua and Hou Yongfeng "The construction and enlightenment of education system of American innovation and entrepreneurship".[J].Research on education in higher engineering 2016(02):7-12.

[4] Deng Qizhong, Zhou zhiqiang” Problems and problems in education system of university students' innovation and entrepreneurship" [J].Innovation and entrepreneurship education, 2014,5(010:33-35.

[5] Liu Zhijun, Hao Jie" Construction and implementation of education system for American innovation and entrepreneurship," [J].University teaching in China, 2016(10):43-47 